\title{
Dependence on Creativity Characteristics as Observed during the Implementation of Laboratory Activities
}

\author{
Lilia Ellany Mohtar'1, Lilia Halim¹, Seth Sulaiman² \\ ${ }^{1}$ Faculty of Education, National University of Malaysia, Bangi, Malaysia. \\ ${ }^{2}$ Faculty of Education, University Teknologi Malaysia, Johor Bahru, Malaysia \\ Email: lilelny@gmail.com
}

Received 30 April 2015; accepted 23 June 2015; published 26 June 2015

Copyright (C) 2015 by authors and Scientific Research Publishing Inc.

This work is licensed under the Creative Commons Attribution International License (CC BY).

http://creativecommons.org/licenses/by/4.0/

(c) (i) Open Access

\section{Abstract}

A person's creativity can be elicited through observations made upon his/her behaviour and personality characteristics which are in turn termed as creativity characteristics. Physics Practical Work (PPW) is a form of instruction which is intended to foster a creative culture in schools in which large numbers of students can be engaged in an environment where creativity flourishes. However, there are criticisms leveled against the effectiveness of PPW in developing creativity among students as indicated by the emergence of the creativity characteristics. Besides being involved in PPW as a requirement of the course SPN3231, 12 respondents of the study comprising final year undergraduate physics education students participated in a Physics Innovative Project (PIP) whereby they had to modify or devise an alternative method(s) for teaching physics topics which they had earlier conducted in PPW. Seven dominant creativity characteristics constructs were incorporated into a well-validated Structured Interview Checklist ( 27 items) and an Observation Checklist (37 items). All data were analysed using the Interactive Qualitative Analysis Model by Miles and Huberman (1994). Results of the study indicated that PIP fostered frequent emergence of creativity characteristics much better as compared to PPW.

\section{Keywords}

Creative Learning Environment, Creativity Characteristics, Physics Practical Work, Physics Innovative Project

\section{Introduction}

Creativity is an important attribute and asset in the development of human capital. The national economy de-

How to cite this paper: Mohtar, L. E., Halim, L., \& Sulaiman, S. (2015). Dependence on Creativity Characteristics as Observed during the Implementation of Laboratory Activities. Creative Education, 6, 1168-1177. 
pends very much on the degree of creativity and innovativeness of the people (KPM, 2013). The education sector, perceived to be the most important sector of the society, faces great challenges in its effort to develop creativity amongst its teachers and students. Laboratory activities are ideal venues which provide opportunities for students to develop their cognitive, psychomotor and affective domains. However, the fostering of a conducive and creative environment depends largely on how teachers organize them. Aside from students and the learning environment, the teacher is the most influential factor in the successful development of creativity and innovation in the classroom (Gorshunova et al., 2014).

Torrance (1970) emphasized that creativity among students could be developed in the process of teaching and learning. This is an indication that teachers have a greater role and responsibility to develop creativity among their students. Failing in this effort could mean failure of the national vision to produce a whole cadre of creative and innovative workforce. In short, national educational programs should be intensified to emphasise the development of creativity and innovation amongst students, teachers and undergraduates. Only with a creative and innovative workforce can a nation prosper and achieve economic growth.

A person's creativity is usually observed through his/her behaviour and personality traits. This is termed as creativity characteristics (Simonton, 2012; Pedersen \& Burton, 2009; Son, 2009). These creativity characteristics are frequently being used in most researches trying to understand concepts related to creativity and innovation (Treffinger, 1992; Simonton, 2012; Pedersen \& Burton, 2009). Knowledge about creativity concepts based on creativity characteristics serves as important guidelines to educators to plan and implement development programs related to creativity (Gorshunova et al., 2014). In this study, a similar approach was undertaken. The instruments developed consisted of items on creativity characteristics adapted from previous research (Foursight Consulting Group, 2004; Sriraman, 2004; Hamza \& Griffith, 2006; Aboukinane, 2007; Pedersen \& Burton, 2009; Rabari et al., 2011).

\section{Theoretical Framework}

According to Pedersen \& Burton (2009), there are about 200 or more creativity characteristics being used in previous researches. Table 1 is a summary of examples of creativity characteristics used by previous researchers as found in the literature. Creativity characteristics comprise both the cognitive and non-cognitive aspects. According to Rabari et al. (2011) creativity is also influenced by non-cognitive aspects such as motivation. A close examination of Table 1 indicates that divergent thinking, problem solving, imagination, uniqueness, curiosity, confidence and openness are dominant characteristics (Cropley \& Cropley, 2010; Cheng, 2004; Sriraman, 2004; Aboukinane, 2007; Hong \& Kang, 2009; Pederson \& Burton, 2009).

Table 1. Summary of creativity characteristics in previous studies.

\begin{tabular}{|c|c|c|c|}
\hline \multicolumn{4}{|c|}{ Creative Characteristics in Previous Studies } \\
\hline Pedersen \& Burton (2009) & Cheng (2004) & Dacey (1985) & Cropley \& Cropley (2010) \\
\hline $\begin{array}{c}\text { Risk taking } \\
\text { Problem solving } \\
\text { Artistic and aesthetic } \\
\text { Intelligent } \\
\text { Analogy } \\
\text { Innovation } \\
\text { Divergent thinking } \\
\text { Openness } \\
\text { Uniqueness } \\
\text { Imagination }\end{array}$ & $\begin{array}{c}\text { Divergent thinking } \\
\text { Uniqueness } \\
\text { Sensitive } \\
\text { Imagination } \\
\text { Synthesis } \\
\text { Interest } \\
\text { Confidence } \\
\text { Valuable } \\
\text { Creativity awareness } \\
\text { Curiosity } \\
\text { Risk taking }\end{array}$ & $\begin{array}{c}\text { Sensitivity } \\
\text { Survive } \\
\text { Divergent thinking } \\
\text { Convergent thinking } \\
\text { Intelligent } \\
\text { Openness } \\
\text { Responsibility } \\
\text { Positive thinking } \\
\text { Uniqueness } \\
\text { Imagination }\end{array}$ & $\begin{array}{c}\text { Uniqueness } \\
\text { Problem Solving } \\
\text { Openness } \\
\text { Risk taking } \\
\text { Confidence } \\
\text { Creativity awareness } \\
\text { Curiosity } \\
\text { Adventurous }\end{array}$ \\
\hline Anderson (1970) & Sriraman (2004) & Hong \& Kang (2009) & Aboukinane (2007) \\
\hline $\begin{array}{c}\text { Sensitive } \\
\text { Flexibility } \\
\text { Fluency } \\
\text { Uniqueness } \\
\text { Divergent thinking } \\
\text { Convergent thinking }\end{array}$ & $\begin{array}{l}\text { Social interaction } \\
\text { Imagination } \\
\text { Heuristic } \\
\text { Intuition }\end{array}$ & $\begin{array}{c}\text { Uniqueness } \\
\text { Problem solving } \\
\text { Ethical } \\
\text { Divergent thinking } \\
\text { Imagination } \\
\text { Curiosity }\end{array}$ & $\begin{array}{c}\text { Divergent thinking } \\
\text { Convergent thinking } \\
\text { Humor } \\
\text { Confidence } \\
\text { Openness }\end{array}$ \\
\hline
\end{tabular}


In this study all the seven creativity characteristics were selected because they formed a strong basis in Treffinger's Model of Creative Learning (Treffinger, 1992). Treffinger's Model of Creative Learning appears at three levels. Level 1 looks at Divergent Functions, Level 2 deals with Complex Thinking and Feeling Processes and Level 3 refers to Involvement in Real Challenges (Figure 1). In this study six creativity characteristics were selected from Treffinger's Level 1 and imagination from Level 2.

Creativity characteristics in Treffinger's Level 1 are associated with basic techniques which are instrumental for moving up to Level 2 and Level 3 which are of a higher order of creativity development. If the basic techniques of creativity in Level 1 are not manifested then it might be difficult for an individual to be creative at Level 2. In his Model of Creative Learning, imagination is considered to be at a higher level of perception and is therefore in Level 2. However, previous studies showed that imagination is a dominant characteristic reflecting creativity and is at par with divergent thinking, uniqueness, problem solving, curiosity, confidence and openness (Cheng, 2004; Sriraman, 2004; Hong \& Kang, 2009). Thus imagination was included in this study.

\section{Background of the Study}

Generally speaking our nation still lags behind in inculcating creativity amongst students. Since schooldays there has been no concerted effort to develop students to be creative and innovative (Haryanti 2009; Gorshunova et al., 2014). Education in Malaysia focuses more on the teaching and learning of concepts without exploring the life environment of students related to the concepts. The lack of contextualization in teaching creates a monotonous learning environment. As a result students are unable to acquire new learning and experiences, and instead rely solely on teachers' knowledge and textbooks. Based on this scenario, students fail to exhibit creativity characteristics and find it difficult to develop creativity.

In the context of the teaching profession, pre-service science teachers should be more involved in the training of laboratory activities such as practical science lessons or innovative science projects. In the context of teacher education, research evidence has indicated that such activities are still lacking and not being undertaken seriously. Cheng (2004) in his study with physics teachers in Hong Kong found that nearly a majority of its physics

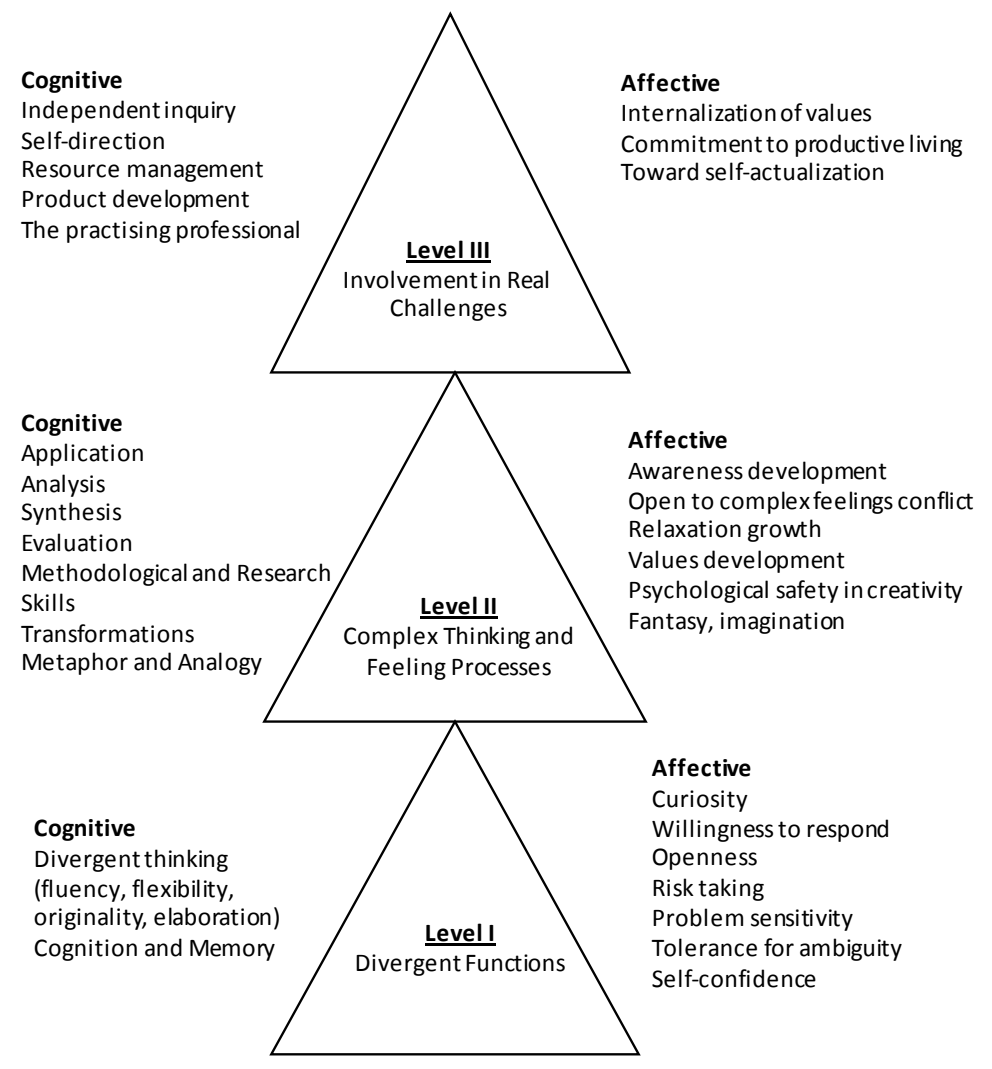

Figure 1. Creative learning model by Treffinger (1992). 
teachers agreed that they received little knowledge and experience related to creativity during their schooldays and teacher training.

Apart from criticisms whichcast doubts on the effectiveness of practical work, previous research evidence indicated otherwise, that it is beneficial to students (Wood, 2006; Hanif et al., 2009; Nurzatulshima et al., 2009; Kim \& Chin, 2011). There were studies which deliberated on the ineffectiveness of practical work (Abu, 2004; Haigh et al., 2005; Schwarz et al., 2008; Yoon 2008; Hanif et al. 2009; Yoon \& Kim, 2009). Both schools of thought justified their claims. Perhaps it is not the means rather it is the planning and organization of the practical work that matters. This includes active participation on the part of the students which depends largely on the healthy interaction of the students with their teachers as well as with the teaching and learning resources (Abu, 2012).

According to Vidal (2010), students can develop skills if they were given the opportunityfor new challenging experiences in their learning and not solely following instructions as given in textbooks in the traditional way, like following a "recipe" approach. Practical work can be compatible to an innovative project if it was properly organized with materials and input which actively engaged the learners (Abu, 2012). Forest \& Faucheux (2011) rationalized that innovative projects promised better opportunities for students to develop their creativity. In this study, it was found that creativity characteristics were highly dependent on the Physics Innovative Project as compared to the Physics Practical Work carried out by the same respondents.

\section{Research Question}

The research question is whether creativity characteristics are independent of laboratory activities. The hypothesis is as follows:

$\mathrm{Ho}=$ Creativity Characteristics are independent of laboratory activities;

$\mathrm{H}_{\mathrm{A}}=$ Creativity Characteristics are dependent on laboratory activities.

\section{Research Medium}

The study involved two research media namely the Physics Practical Work (PPW) and the Physics Innovative Project (PIP) which were incorporated into the Bachelor of Science Education (Physics) programme with the course code SPN3231 for Physics Practical Work II. In this course, final year undergraduate physics education students conducted four weeks of the usual PPW first followed by six weeks of PIP where they had to modify or devise alternative method(s) for teaching physics topics which they had conducted in the PPW. The PPW is designed in line with the requirements of practical physics as stipulated in the Secondary School Integrated Curriculum [Kurikulum Bersepadu Sekolah Menengah (KBSM)]. This was carried out every week for three hours throughoutthe 2011/2012 semester session. For PPW, the respondents used the Form Four standard textbook as reference. The seven experiments conducted are shown in Table 2.

The planning of PIP was done together with the instructor. Table 3 lists the six physics experiments which the students had to either modify for improvement or devise a new method(s) for the same objective. Instructions for

Table 2. List of experiments conducted in Physics Practical Work (PPW).

\begin{tabular}{|c|c|c|}
\hline Experiment & Code & Objective \\
\hline \multirow{2}{*}{ Waves } & E1 & $\begin{array}{l}\text { - To determine the natural frequency of a simple pendulum. } \\
\text { - To observe resonance phenomenon of a simple pendulum. }\end{array}$ \\
\hline & E2 & $\begin{array}{l}\text { - To study patterns of water waves. } \\
\text { - To study resonance of sound waves. }\end{array}$ \\
\hline \multirow{3}{*}{ Electric } & E3 & - To determine factors that influence the resistance of a conductor. \\
\hline & E4 & $\begin{array}{l}\text { - To study series and parallel circuits. } \\
\text { - To determine voltages in series and parallel circuits. }\end{array}$ \\
\hline & E5 & - To determine e.m.f. and resistance in a dry cell. \\
\hline \multirow{2}{*}{ Electronic } & E6 & $\begin{array}{l}\text { - To study the force of a conductor in a magnetic field. } \\
\text { - To determine the interaction of forces in a conductor carrying current in a magnetic field. }\end{array}$ \\
\hline & E7 & - To determine the relationship between base current (ib) and collector current (ic) in a transistor \\
\hline
\end{tabular}


Table 3. List of experiments for Physics Innovative Project (PIP).

\begin{tabular}{ccll}
\hline Experiment & Code & Objective \\
\hline Waves & P1 & - Observe resonance phenomenon of a simple pendulum \\
& P2 & - Relationship between potential difference and current passing through an ohmic and non-ohmic conductor. \\
Electric & P3 & - & Series and parallel circuits. \\
& P4 & - E.m.f. and resistance in a dry cell. \\
& P5 & - Force on a conductor in a magnetic field. \\
Electronic & P6 & - Factors affecting the magnitude of force in a conductor carrying current in a magnetic field. \\
&
\end{tabular}

innovative activities were found in the Form Five textbook. A total of six weeks at two hours per week were allocated to provide sufficient time for creative and innovative ideas to emerge. Students embarked on the PIP immediately after they had completed the PPW.

\section{Methodology}

The quantitative data analysed in this paper is part of the data from the main study which is a qualitative research of a general case study. Data collection was based on well-controlled observations which were conducted and video-taped throughout the implementation of the laboratory techniques and all data was noted and transcribed. A similar process was carried out with the semi-structured interviews. Creativity characteristics were accounted for using the checklists when observing video-taped activities several times both for PPW and PIP. The 12 respondents constituted a population of third year students pursuing their Bachelor of Science (Physics Education) at the Faculty of Education, Universiti Teknologi Malaysia. As a compulsory requirement of the program, these students enrolled in the course code named SPN 3231 Laboratory Activities comprising PPW and PIP in Semester II Session 2011/12. The respondents consisted of 5 males (Malay), 5 females (Malay) and 2 females (Chinese) with ages ranging from 22 - 25 years. These students were expected to teach physics subject in Malaysian Secondary Schools upon completion of their degree which was at the end of fourth year (final year).

\subsection{Research Procedure}

\section{i) Observation}

Three types of observations were conducted: 1) semi-structured observation, 2) non-participant observation, and 3) direct observation. Observations involved looking at respondents' behaviour, products, their interaction while performing tasks, respondents' overt emotional behaviour as well as any form of behaviour which reflected creativity characteristics. Non-participant observations and the use of video throughout the activities minimized researcher interference.

ii) Interview

The semi-structured interview was carried out on all 12 respondents in pairs. Each pair was interviewed twice, once upon completion of the PPW and the other interview upon completion of the PIP. Video recording technique was used in this study so as to ensure that every creativity characteristic was accounted for.

\subsection{Research Instruments}

As mentioned earlier two instruments were developed based on adaptations from previous researches (Foursight Consulting Group, 2004; Sriraman, 2004; Hamza \& Griffith, 2006; Aboukinane, 2007; Pedersen \& Burton, 2009; Rabari et al., 2011). The instruments were well-validated. Both the instruments had the same item construct with seven creativity characteristics specifically selected by the researchers (divergent thinking, problem solving, uniqueness, imagination, openness, confidence and curiosity) in line with the research objective.

i) Observation Checklist

The observation checklist contained 37 items according to the characteristics specifically selected for con- 
ducting direct observations. Items of the observation checklist reflected creativity characteristics to be expected. Items were also adapted from previous researches (Torrance, 19795; Cropley \& Cropley, 2010; Cheng, 2004; Sriraman, 2004; Azhar et al., 2006; Aboukinane, 2007; Villalba, 2008).

ii) Interview Sessions

Guidelines for the interview sessions were also prepared. The first interview session was conducted at the end of the PPW activity and the second session at the end of PIP. Both guidelines consisted of 27 items reflecting the seven dimensions of creativity characteristics which were determined earlier.

iii) Validity of Instruments

Since the main study was purely qualitative in nature only the construct, content and criteria validities for both instruments were determined (Campbell \& Fiske, 1959). For this purpose two experts, namely a lecturer of physics education at UTM and a senior Head of the Physics Panel in a secondary school were appointed. In addition, for validation purposes both instruments were piloted employing three pre-service teachers who were not involved in the main study.

\section{Analysis}

\section{Data from Observation Checklist}

Seven creativity characteristics which constituted a validated instrument of the study were observed and videotaped. A semi-structured interview using a parallel instrument was conducted on all the 12 respondents (final year physics undergraduate students). During the observation, creativity characteristics exhibited by the respondents were recorded based on the observation checklist. The videotaped observations were also repeatedly viewed to ensure that all creativity characteristics were noted. Data was also analysed from evidence derived from direct observations (Chua, 2006; Lim, 2007). All data from observations were organized and analysed in order to form generalizations for both PPW and PIP (Creswell \& Clark, 2007).

\section{Data from Interview}

The interview analysis was based on the Interactive Qualitative Analysis Model by Miles \& Huberman (1994). According to Miles \& Huberman (1994), there are three stages of activities during the process of interactive analysis namely, data reduction, data display, making conclusions and verifying results. Upon completion of the data analysis derived from observations and interviews that were conducted, the qualitative data was quantified in terms of the frequency of occurrence of creativity characteristics. This is for the purpose of answering the research question. Creswell \& Clark (2007) reiterated that analysed qualitative data can be transformed to quantitative data in order to answer the research objective. Transformation of data is also allowable if it facilitates providing a satisfactory description and visualization of the social phenomena under investigation (Creswell \& Clark, 2007).

\section{Results}

Table 4 is a $2 \times 7$ contingency table of total creativity characteristics as observed during laboratory activities and recorded during interview sessions. This is a small sample of respondents to be used in a significantly statistical technique such as non-parametric Chi Square.

$\mathrm{Ho}=$ Creativity characteristics are independent of laboratory activities.

$\mathrm{H}_{\mathrm{A}}=$ Creativity characteristics are dependent on laboratory activities.

Table 5 illustrates the analysis of creativity characteristics derived from contingency Table 4. Non-parame-

Table 4. Contingency table of creativity characteristics as observed during laboratory activities and interview sessions.

\begin{tabular}{ccccccccc}
\hline Creativity Characteristics & DS & PS & UN & IM & OP & CU & SC & Total \\
\hline Physics Practical Work & 7 & 0 & 0 & 6 & 16 & 10 & 4 & 43 \\
Physics Innovative Work & $(7.43)$ & $(5.57)$ & $(1.33)$ & $(4.78)$ & $(10.35)$ & $(7.43)$ & $(6.11)$ & 19 \\
Totals & $(20.57)$ & $(15.43)$ & $(3.67)$ & $(13.22)$ & $(28.65)$ & $(20.57)$ & $(16.90)$ & 119 \\
& 28 & 21 & 5 & 18 & 39 & 28 & 23 & 162 \\
\hline
\end{tabular}

Legend: DT = Divergent thinking; PS = Problem solving; UN = Uniqueness; IM = Imagination; OP = Openness; CU = Curiosity; $\mathrm{SC}=$ Self-confidence; Values in brackets () denote expected values. 
Table 5. Comparison of chi square for a two-by-seven table.

\begin{tabular}{|c|c|c|c|c|c|}
\hline (1) Cell & (O) Observed & (E) Expected & $(\mathrm{O}-\mathrm{E})$ & $(\mathrm{O}-\mathrm{E})^{2}$ & $(\mathrm{O}-\mathrm{E})^{2} / \mathrm{E}$ \\
\hline 1 & 7 & 7.34 & -0.43 & 0.1849 & 0.0249 \\
\hline 2 & 0 & 5.57 & -5.57 & 31.0249 & 5.5700 \\
\hline 3 & 0 & 1.33 & -1.33 & 1.7689 & 1.3300 \\
\hline 4 & 6 & 4.78 & 1.22 & 1.4884 & 0.3114 \\
\hline 5 & 16 & 10.35 & 5.65 & 31.9225 & 3.0843 \\
\hline 6 & 10 & 7.43 & 2.57 & 6.6049 & 0.8890 \\
\hline 7 & 4 & 6.11 & -2.11 & 4.4521 & 0.7287 \\
\hline 8 & 21 & 20.57 & 0.43 & 0.1849 & 0.0090 \\
\hline 9 & 21 & 15.43 & 5.57 & 31.0249 & 2.0107 \\
\hline 10 & 5 & 3.67 & 1.33 & 1.7689 & 0.4820 \\
\hline 11 & 12 & 13.22 & -1.22 & 1.4884 & 0.1126 \\
\hline 12 & 23 & 28.65 & -5.65 & 31.9225 & 1.1142 \\
\hline 13 & 18 & 20.57 & -2.57 & 6.6049 & 0.3211 \\
\hline 14 & 19 & 16.90 & 2.1 & 4.4100 & 0.2609 \\
\hline \multicolumn{6}{|c|}{$\sum(\mathrm{O}-\mathrm{E})^{2} / \mathrm{E}=16.2488$} \\
\hline \multicolumn{6}{|c|}{$\gamma 2=16.2488>12.59($ table $)$} \\
\hline
\end{tabular}

tric Chi Square statistics was used with (7-1) (2-1) degree of freedom $(\alpha=0.05)$. Since $\gamma 2=16.6015>12.59$ at $\alpha=0.05$ and $\mathrm{df}=6$ (table) How as rejected. Thus, creativity characteristics are dependent on laboratory activities which are in favour of the Physics Innovative Project in this study.

\section{Discussion}

In this study, results from Chi Square indicated that the emergence of creativity characteristics were dependent on PIP than on PPW. Creativity characteristics were more frequently exhibited by the students in PIP as compared to PPW which provides evidence that creativity requires a conducive learning environment. Thus PIP appeared to be a better instructional technique for the development of creativity characteristics in this study. This is supported by Forest \& Faucheux (2011) who reiterated that innovative projects are a more rational practice for the preparation of a workforce who are excellent in academic status and skills. Innovative projects provide ample opportunities for students to create new ideas, paradigms and foster a good learning culture (Forest \& Faucheux, 2011).

Innovative projects are more challenging and inevitably compel pre-service teachers to be competitively creative. This compulsion brings about a positive effect in the development of creativity (Torrance, 1970). One cannot disclaim the importance of PPW in the process of learning science particularly physics, be it in schools or in universities (Sneddon et al., 2009). However, there needs to be a revisit on the organization of the content and activities of PPW. Almost all of the pre-service teachers in this study were products of the school physics programme and were therefore familiar with what was expected of them in PPW. In this study, PPW comprised topics at form five level which they had also studied when they were in school. A lot of criticism has been levelled against PPW as an activity having characteristics of a recipe book (Abu, 2004). As a result, it lacks efficacy for the satisfactory manifestation of creativity characteristics.

Vidal (2010) strongly felt that students could enhance their personal skills if they were given opportunities to be involved in new learning experiences that would activate their cognitive skills rather than follow a "recipe" approach in learning. The former development would not be realised in a disorganized PPW. Generally, Haryanti (2009) in her study found that teaching and learning in Malaysia focussed more on text books and teachers' 
knowledge withless venturing into the realm of challenging real life situations. As a result, students find lessons monotonous and devoid of opportunities to be creative and innovative. This is further corroborated by studies undertaken by Mohamad \& Nasruddin (2008) which showed that the majority of teachers in Malaysia did not place much emphasis or effort on the development of creativity in their lessons.

In the analysis of the questionnaire in her main study given to respondents at the end of PPW and PIP, Mohtar $(2012,2013)$ grouped the responses under Strongly Disagree, Disagree and Neutral as negative feedback on creativity characteristics whilst, Agree and Strongly Disagree as positive feedback. She found that except for Openness which registered no percentage difference, the average percentage difference on positive feedback between PPW and PIP for the remaining six creativity traits ranged from about 20 to $50 \%$ in favour of PIP. In this main study all evidence reflected strongly that PIP encouraged better emergence of creativity characteristics compared to PPW. This result corroborated with findings from a study carried out by Forest \& Faucheux (2011). The hypothesis is now proven based on the results of this study that creativity characteristics are significantly dependent on PIP. This result completes the triangulation process conclusively.

\section{Conclusion}

Creativity is vital at every level of the social strata. Life activities would come to a halt in the absence of creativity. Every individual is born creative. The difference in the level of creativity among individuals is a matter of degree. A person gifted with a high degree of creativity requires little effort for creativity development. In the present study, creativity characteristics were observed using well-validated instruments. Results of the study indicated that PIP provided ample opportunities for pre-service teachers to exhibit creativity characteristics as compared to PPW. Furthermore, PIP provided the pre-service teachers a more challenging experience in acquiring knowledge and skills which would be of immense benefit to them when they graduated and served in schools. On the other hand, PPW in this study gave less impact on their knowledge and experience because PPW which they themselves experienced during their schooldays was merely carrying out activities based on instructions given in the textbook. There is less emphasis on the development of thinking skills and creativity.

It is not to disclaim that PPW is an important instructional technique, however the activities need to be relevant in fostering the development of thinking skills and creativity (Abu, 2102; Forest \& Faucheux, 2011). A process approach in learning is vital for effective understanding of physics concepts on the part of the students. Incidentally, these process approaches come under different terminologies such as problem-based learning, learning through inquiry, cooperative learning, student-centred learning, etc. These approaches activate all the required learning domains for effective acquisition of conceptual knowledge (cognitive), development of skills (cognitive and affective), psychomotor and attitude, motivation and interest (affective). It will be interesting to find out which of these factors contribute most to students' performance in physics which is of great concern to physics educators. Up to date, only few researches have been conducted to examine the status of scientific creativity of secondary school students (Hu \& Adey, 2002).

The implications of this study suggest that i) institutions of higher learning, particularly teacher education, should encourage more instructional techniques enriched with activities such as PIP which will foster the development of a creative culture among students, ii) PPW which is a scientist's handmaid method for verifying results and acquiring scientific knowledge needs to be revisited and be effectively re-organized. This can give more freedom for pre-service teachers and students in general to think in a broader perspective and enable them to contribute to decision-making whenever necessary to solve impending problems, and that iii) PPW enriched with activities can provide a conducive environment to encourage students to be more creative (Abu, 2012). A more creative person always exhibits more creativity characteristics (Dacey, 1985).

Finally, creativity is still broad and diverse in its perspective. As a form of knowledge, it still lacks satisfactory epistemological status, as such contemporary researchers are much involved in the development of scientific creativity models and measurements (Hu \& Adey, 2002; Park, 2012; Sak \& Ayas, 2013). This augurs well for the application of a reliable and valid scientific creativity model and measurement for future in-depth quantitative studies at doctoral level to determine the extent in which scientific creativity and other variables including personality traits affect students' performance in physics at the secondary school level.

\section{References}

Aboukinane, C. (2007). A Qualitative Study of Creative Thinking Using Experiential. Ph.D. Thesis, College Station: Texas 
A\&M University.

Abu, H. H. (2004). Status MakmaldanPelaksanaan Amali Fizik Di Sekolah-Sekolah Daerah Kuala Pilah, JelebudanJempol $(K P J J)$. Project Report, Johor Bahru: Universiti Teknologi Malaysia.

Abu, H. H. (2012). Development of an Enriched Method for Introductory Physics Laboratory Work and Its Effects on Students' Learning Outcomes. Ph.D. Thesis, Johor Bahru: Universiti Teknologi Malaysia.

Anderson, H. H. (1970). Creativity and Its Cultivation. Michigan: Penguin Books.

Azhar, A. H., Mohd, K. B., Mohammad, F. O., \& Othman A. K. (2006). Reka Cipta \& Inovasi Dalam Perspektif Kreativiti. Johor Bahru: Penerbit UTM.

Cheng, V. M. Y. (2004). Developing Physics Learning Activities for Fostering Student Creativity in Hong Kong. Asia-Pacific Forum on Science Learning and Teaching, 5, 1-15.

Chua, Y. P. (2006). KaedahdanStatistikPenyelidikan. Kuala Lumpur: McGraw Hill.

Creswell, J. W., \& Clark, V. C. P. (2007). Designing and Conducting Mixed Methods Research. Thousand Oaks, California: SAGE Publication.

Cropley, D., \& Cropley, A. (2010). Recognizing and Fostering Creativity in Technological Design Education. International Journal Technology Design Education, 20, 345-335. http://dx.doi.org/10.1007/s10798-009-9089-5

Dacey, S. J. (1985). Fundamentals of Creative Thinking. San Francisco: Jossey-Bass.

Forest, J., \& Faucheux, M. (2011). Stimulating Creative Rationality to Stimulate Innovation. Creativity and Innovation Management, 20, 207-212. http://dx.doi.org/10.1111/j.1467-8691.2011.00603.x

Foursight Consulting Group Inc. (2004). How Would You Rate Your Creativity? http://www.foursightconsulting.com

Gorshunova, N. K., Medvedev, N. V., \& Razdorskaya, O. V. (2014). The Significance of High School Teacher's Creativity for Innovation Pedagogical Practice. Journal of International Scientific Publications, 12, 607-614.

Haigh, M., France, B., \& Forret, M. (2005). Is "Doing Science" in New Zealand Classrooms an Expression of Scientific Inquiry? International Journal of Science Education, 27, 215-226. http://dx.doi.org/10.1080/0950069042000276730

Hamza, M. K., \& Griffith, K. G. (2006). Fostering Problem Solving and Creative Thinking in the Classroom: Cultivating a Creative Mind! National Forum of Applied Educational Research Journal-Electronic, 19, 1-30.

Hanif, M., Sneddon, P. H., Al-Ahmadi, F. M., \& Reid, N. (2009). The Perceptions, Views and Opinions of University Students about Physics Learning during Undergraduate Laboratory Work. European Journal of Physics, 30, 85-96. http://dx.doi.org/10.1088/0143-0807/30/1/009

Haryanti, M. A. (2009). Ketekunan, Kreativiti dan Inovasi Di Kalangan Pelajar UTHM. M.Ed Thesis, Johor Bahru: Universiti Teknologi Malaysia.

Hong, M., \& Kang, N. H. (2009). South Korean and the US Secondary School Science Teachers' Conceptions of Creativity and Teaching for Creativity. International Journal of Science and Mathematics Education, 8, 821-843.

Hu, W., \& Adey, P. (2002). A Scientific Creativity Test for Secondary School Students. International Journal of Science Education, 24, 389-403. http://dx.doi.org/10.1080/09500690110098912

Kementerian Pendidikan Malaysia (2013). LaporanTahunanPelan Pembangunan Pendidikan Malaysia. Putrajaya: KPM.

Kim, M., \& Chin, C. (2011). Pre-Service Teachers' Views on Practical Work with Inquiry Orientation in Textbook-Oriented Science Classrooms. International Journal of Environmental and Science Education, 6, 23-37.

Lim, C. H. (2007). Penyelidikan Pendidikan: Pendekatan Kuantitatif dan Kualitatif. Selangor: McGraw-Hill.

Miles, M. B., \& Huberman, M. A. (1994). Qualitative Data Analysis: A Sourcebook of New Methods. Baverly Hills, CA: SAGE Publication.

Mohamad, M., \& Nasruddin, Y. (2008). Halangan-HalanganKepada Usaha Memupuk Kreativiti Di Kalangan Pelajar. Proceeding from the National Conference on Soft Skill and Social Well-Being. 18-19 August 2008, Mahkota Hotel Melaka: Pusat Bahasa dan Pembangunan Insan, UTeM.

Mohtar, L. E. (2012). Ciri-CiriKreativitiBakal Guru FizikDalamLatihanAmaliFizik Dan ProjekInovasiFizik. M.Ed. Dissertation, Johor Bahru: Universiti Teknologi Malaysia.

Mohtar, L. E. (2013). Comparison between Characteristics of Creativity in Physics Practical Work and Physics Innovative Project among Pre-Service Physics Teacher. Jurnal Teknologi, 63, 85-89.

http://dx.doi.org/10.11113/it.v63.2015

Nurzatulshima, K., Halim, L., Osman, K., \& T. Subahan, M. M. (2009). Pengurusan Penglibatan Pelajar dalam Amali Sains. Jurnal Pendidikan Malaysia, 34, 205-217.

Park, J. (2012). Developing the Format and Samples of Teaching Materials for Scientific Creativity in the Ordinary Science Curriculum-Including Teachers' Practice and Reflection. Journal of a Korean Association for Science Education, 32, 446- 
466.

Pedersen, E. L., \& Burton, K. L. (2009). A Concept Analysis of Creativity: Uses of Creativity in Selected Design Journals. Journal of Interior Design, 35, 15-33. http://dx.doi.org/10.1111/j.1939-1668.2009.01025.x

Rabari, J. A., Indoshi, F. C., \& Omusonga, T. O. (2011). Correlates of Divergent Thinking among Secondary School Physics Students. International Research Journals, 2, 982-996.

Sak, U., \& Ayas, M. B. (2013). Creative Scientific Ability Test (C-SAT): A New Measure of Scientific Creativity. Psychological Test and Assessment Modeling, 55, 316-329.

Schwarz, C., Gunckel, K., Smith, E., Enfield, M., \& Tsurusaki, B. (2008). Helping Elementary Preservice Teachers Learn to Use Curriculum Materials for Effective Science Teaching. International Journal of Science Education, 92, 345-377.

http://dx.doi.org/10.1002/sce. 20243

Simonton, K. D. (2012). Teaching Creativity: Current Findings, Trends and Controversies in the Psychology of Creativity. Teaching of Psychology, 39, 217-222. http://dx.doi.org/10.1177/0098628312450444

Sneddon, P. H., Slaughter, K. A., \& Reid, N. (2009). Perceptions, Views and Opinions of University Students about Physics Learning during Practical Work at School. European Journal of Physics, 30, 1119-1129. http://dx.doi.org/10.1088/0143-0807/30/5/018

Sriraman, B. (2004). The Characteristics of Mathematical Creativity.The Mathematics Educator, 14, 19-34.

Torrance, E. P. (1995). Why Fly? A Philosophy of Creativity. Norwood, NJ: Ablex Publishing Corporation.

Torrance, P. E. (1970). Creative Learning and Teaching. New York: Harper and Row.

Treffinger, D. J., Isaken, S. G., \& Firestein, R. L. (1992). Theoretical Perspectives on Creative Learning and Its Facilitation: An Overview. The Journal of Creative Behaviour, 17, 9-17. http://dx.doi.org/10.1002/j.2162-6057.1983.tb00970.x

Vidal, R. V. V. (2010). Creative Problem Solving: An Applied University Course. Pesquisa Operacional, 30, 405-426. http://dx.doi.org/10.1590/s0101-74382010000200009

Villalba, E. (2008). On Creativity: Toward an Understanding of Creativity and its Measurements. Luxembourg: European Communities.

Wood, C. (2006). The Development of Creative Problem Solving in Chemistry. Chemistry Education Research and Practice, 7, 96-113. http://dx.doi.org/10.1039/B6RP90003H

Yoon, H. G. (2008). Elementary Teachers' Dilemmas of Teaching Science Practical Work. Journal of Korean Elementary Science Education, 27, 102-116.

Yoon, H. G., \& Kim, M. (2009). Collaborative Reflection Collaborative Reflection through Dilemma Cases of Science Practical Work during Practicum. International Journal of Science Education, 32, 283-301. 